\title{
Rancangan Proteksi Otomatis menggunakan Motion Detector, Radio Frequency Identification (RFID), dan CCTV Berbasis SMS Gateway di Laboratorium Airfield Lighting System Politeknik Penerbangan Surabaya
}

\author{
Kustori $^{1}$, Afan Setiawan ${ }^{2}$ \\ ${ }^{1,2)}$ Politeknik Penerbangan Surabaya \\ J1. Jemur Andayani I, No. 73 Surabaya 60236 \\ Email : kustoriatkp@gmail.com
}

\begin{abstract}
ABSTRAK
Politeknik Penerbangan Surabaya memiliki Laboratorium Airfield Lighting System yang sudah menggunakan Fingerprint dalam pengoperasiannya, tetapi karena kurangnya pengawasan terhadap suatu alat yang akan dipinjam mengakibatkan hilangnya barang atau peralatan yang ada pada laboratorium.

Permasalahan yang dikaji dalam penelitian ini adalah belum adanya pengawasan terhadap peminjaman alat yang ada pada laboratorium Airfield Lighting System serta kurangnya sisi keamanan pada laboratorium. Penulisan penelitian ini bertujuan untuk merancang suatu sistem proteksi otomatis pada laboratorium Airfield Lighting System Politeknik Penerbangan Surabaya dengan menggunakan Motion Detector sebagai pendeteksi gerakan manusia, Radio Frequency Identification (RFID) sebagai pendeteksi peralatan dan CCTV sebagai Monitor keadaan yang ada pada laboratorium. Pengontrolan dilakukan secara wireless yaitu dengan menggunakan media Short Message Service (SMS).

Hasil dari rancangan ini adalah terciptanya suatu alat bantu untuk memonitor peminjaman alat yang ada pada laboratorium dan menambah sistem keamanan untuk mencegah terjadinya pencurian pada laboratorium Airfield Lighting System
\end{abstract}

Kata Kunci : Proteksi Otomatis, Motion Detector, Radio Frequency Identification (RFID), Closed Circuit Television (CCTV), Mikrokontroler, SMSGateway

\section{PENDAHULUAN}

Politeknik Penerbangan Surabaya merupakan institusi di bawah naungan Badan Pengembangan Sumber Daya Manusia Perhubungan yang mendidik dan mengasuh taruna yang akan menjadi penerus bangsa dengan segala dedikasinya, khususnya dalam bidang penerbangan.

Banyaknya jumlah Laboratorium di Politeknik Penerbangan Surabaya serta lemahnya pengawasan terhadap peminjaman alat di laboratorium, seringkali dimanfaatkan oleh pihak yang tidak bertanggung jawab untuk mengambil barang barang yang ada di laboratorium. Sarana pengaman seperti CCTV juga tidak selalu ada di tiap laboratorium. Maka penulis bermaksud untuk membuat alat bantu untuk memonitor peminjaman alat yang ada di laboratorium dan menambah sistem keamanan untuk mencegah terjadinya pencurian di laboratorium Politeknik Penerbangan Surabaya. Pada saat ini laboratorium pada Politeknik Penerbangan sudah menggunakan Fingerprint untuk mencegah orang yang tidak dikenal masuk dalam ruangan, tetapi tidak menutup kemungkinan pencuri berasal dari orang dalam yang sudah tau password ataupun lolos dari sensor Fingerprint. Karena itulah penulis membuat rancangan proteksi ruangan dengan alarm dan sms gateway yang dapat memudahkan untuk monitor, menutup secara otomatis pintu terluar dan sebagai petunjuk letak ruangan mana yang telah dimasuki oleh pencuri. 


\section{METODE PENELITIAN}

\section{Kondisi Saat Ini}

Di Politeknik Penerbangan Surabaya sudah didirikan bangunan-bangunan, seperti laboratorium terintegrasi, gedung serba guna, gedung utama, serta bangunan-bangunan lain, semua bangunan tersebut bahkan ada yang sudah memiliki tingkat keamanan yang cukup tinggi seperti fingerprint, password maupun CCTV. SOP (standart operasional prosedur) sudah diterapkan guna mencegah terjadi adanya pencurian.

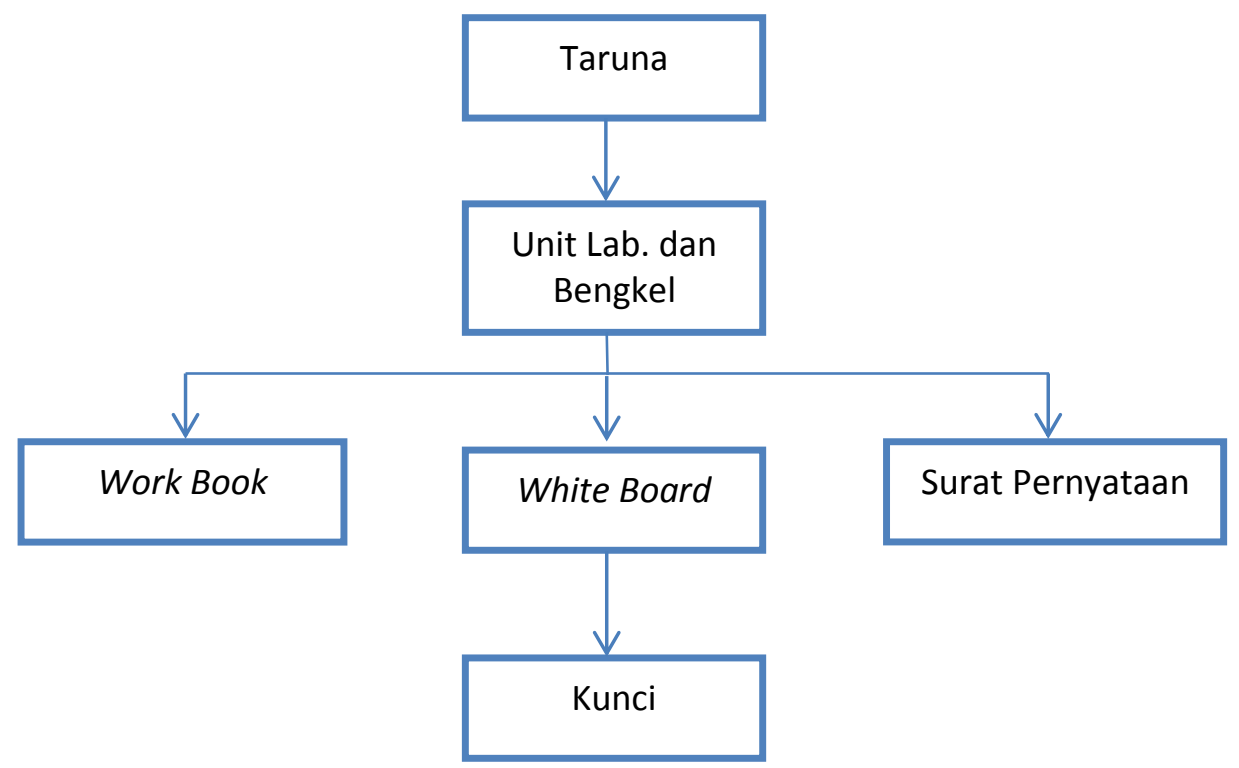

Gambar 1. Standar Operasional Prosedur peminjaman kunci laboratorium

Langkah yang harus dilakukan sebelum meminjam kunci laboratorium adalah mengisi buku Work book peminjaman laboratorium yang akan digunakan, yang kedua mengisi data alat apa yang akan gunakan, siapakah Dosen atau Instruktur yang mendampingi pada saat praktikum, dan yang terakhir adalah mengisi surat pernyataan bahwa bertanggung jawab penuh atas laboratorium saat itu termasuk kebersihan, kerusakan alat, maupun ada maupun hilangnya barang dilaboratorium. Dengan adanya standar operasional prosedur diharapkan dapat mengurangi terjadinya pencurian, tetapi karena kurangnya pengawasan serta lemahnya sisi keamanan tidak bisa mencegah jika terjadi suatu pencurian barang pada laboratorium.

\section{Kondisi yang Diinginkan}

Dengan dibuatnya " Rancangan Proteksi Otomatisasi Menggunakan Motion Detector, Radio Frequency Identification (RFID) Dan CCTV Berbasis SMS Gateway Di Laboratorium Airfield Lighting System Politeknik Penerbangan Surabaya" apabila terjadi indikasi adanya pencurian maka alat pengaman otomatis ini akan bekerja, menutup pintu terluar yang ada pada laboratorium, mengaktifkan alarm, dan memberikan peringatan berupa sms kepada pihak keamanan bahwa sedang terjadi adanya pencurian di laboratorium. Alat ini juga berfungsi sebagai monitor untuk mengawasi peminjaman alat yang ada pada laboratorium.

Berikut merupakan Flowchart dari kondisi yang diinginkan. Secara keseluruhan blog diagram dijelaskan seperti gambar di bawah ini: 


\section{Monitor}

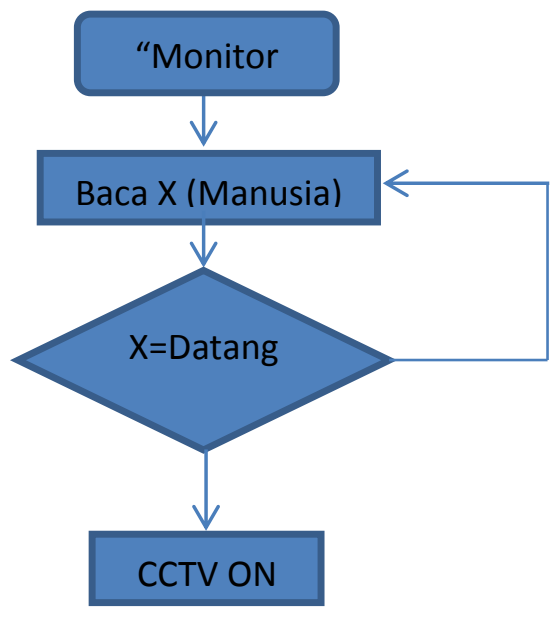

Gambar 2. Flowchart Monitor peminjaman alat pada laboratorium

Pada gambar Flowchart diatas menjelaskan kondisi yang diinginkan dengan menggunakan sistem pengontrolan melalui SMS Gateway. Ketika ada yang akan meminjam peralatan yang ada pada laboratorium maka cukup mengetik "Monitor ON" maka sensor yang akan bekerja adalah Motion Detector dan CCTV, Motion Detector berfungsi sebagai pendeteksi kedatangan maupun kembalinya seseorang di laboratorium dan CCTV berfungsi menampilkan situasi dan keadaan pada laboratorium.

\section{Alarm}

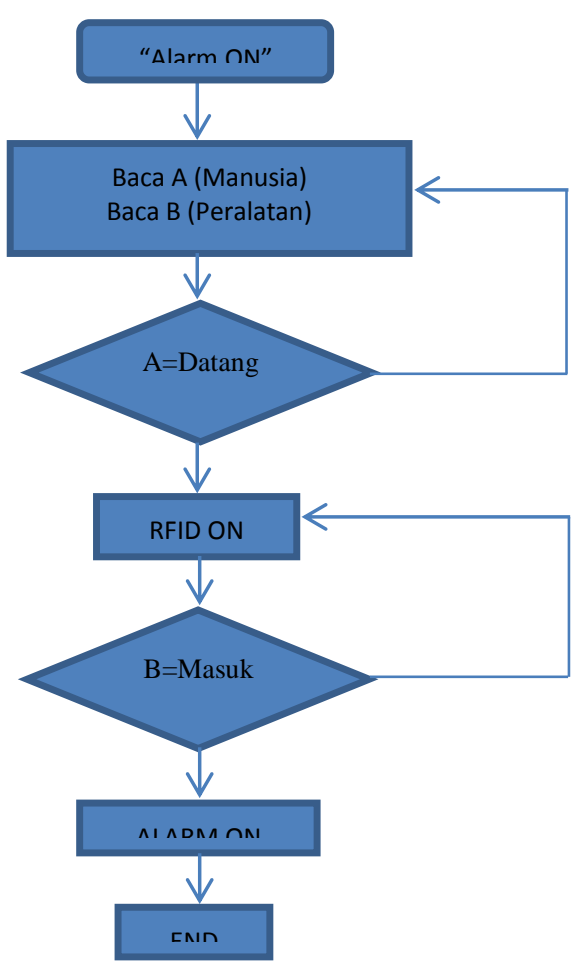

Gambar 3. Sistem keamanan yang ada pada laboratorium

Pada gambar Flowchart diatas menjelaskan kondisi yang diinginkan dengan menggunakan sistem pengontrolan melalui SMS Gateway. Ketika ada yang akan meminjam 
peralatan yang ada pada laboratorium maka cukup mengetik "ALARM ON" maka sensor yang akan bekerja adalah Motion Detector dan RFID. Jika Motion Detector mendeteksi kedatangan seseorang maka RFID akan berkerja, dan jika RFID tersebut mendeteksi peralatan yang akan memasuki pintu yang sebelumnya telah dipasang Motion Detector dan RFID maka secara otomatis sensor tersebut akan mengaktifkan alarm, menutup pintu terluar yang ada di laboratorium, dan mengirim sms ke pihak security atau pihak keamanan.

Pada rancangan alat yang di inginkan, penulis mempunyai gambar blok diagram rancangan seperti dibawah ini :

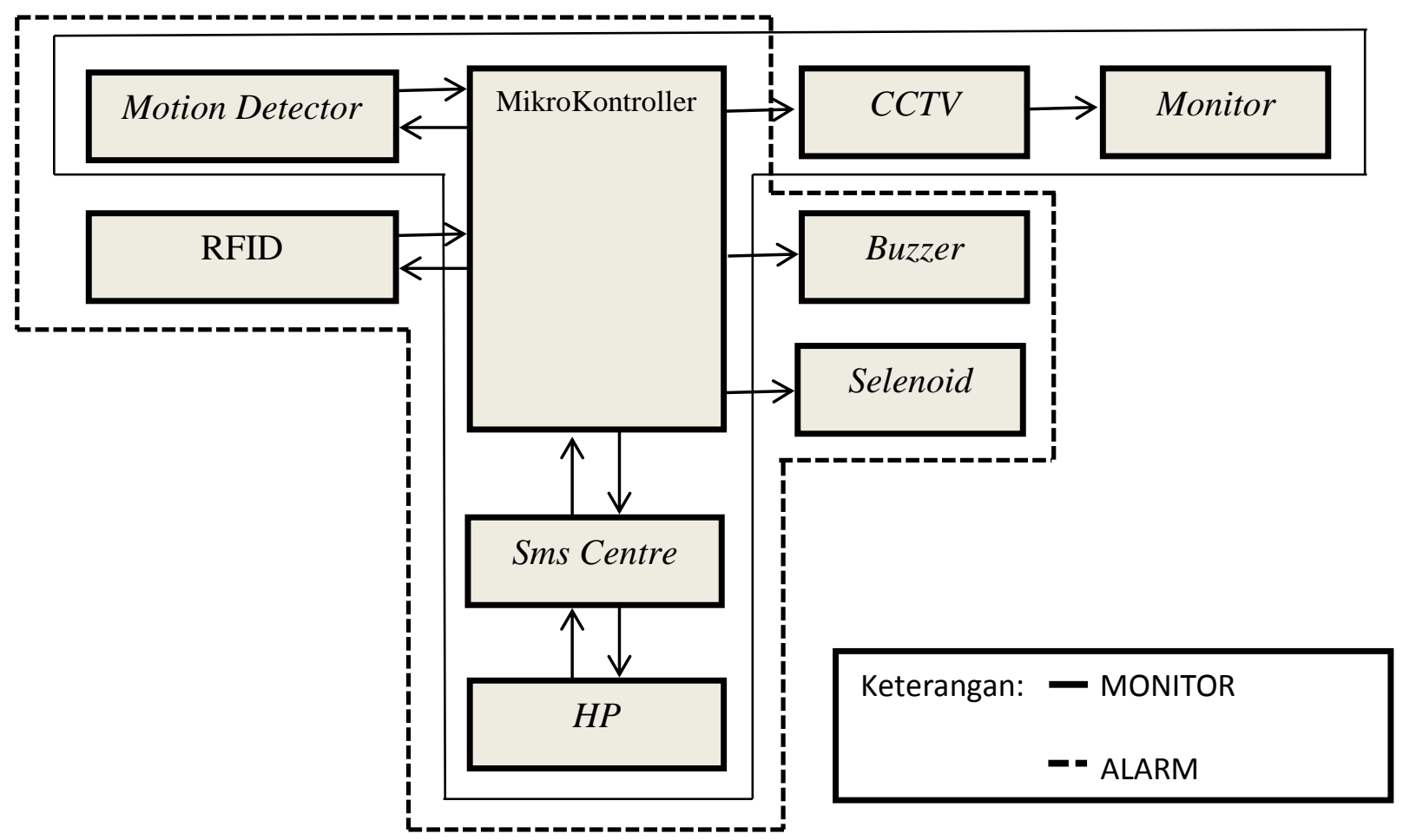

Gambar 4. Blok Diagram Rancangan Alat

Penjelasan Blok Diagram Rancangan :

Pada blok diagram rancangan ini pengontrolan dilakukan dengan cara manual push button dan dengan wireless (sms gateway), pengontrolan secara manual dilakukan apabila terjadi error pada modem. Untuk sistem "Monitor", motion detector akan mendeteksi gerakan seseorang lalu mengirimkan data kepada mikrokontroller yang selanjutnya memberikan perintah ke CCTV untuk menampilkan keadaan atau situasi di laboratorium yang sudah terhubung ke dalam monitor server. Untuk sistem "Alarm" diaktifkan apabila dalam kondisi lecture off atau ketika monitor server tidak ada yang berjaga, ketika alarm dihidupkan maka motion detector berfungsi kembali sebagai pendeteksi gerakan seseorang lalu mengirimkan data kepada mikrokontroller yang selanjutnya memberikan perintah ke RFID untuk mendeteksi peralatan yang ada di laboratorium mendekati pintu atau tidak. Jika RFID mendeteksi peralatan yang mendekati pintu maka RFID mengirimkan sinyal ke mikrokontroller untuk mengaktifkan selenoid yang berfungsi sebagai pengunci pintu terluar yang ada di laboratorium, mengaktifkan buzzer/alarm yang berfungsi sebagai tanda peringatan berupa suara, dan mengirimkan sms melalui modem wavecom kepada pihak security atau pihak keamanan lain bahwa terjadi indikasi pencurian didalam laboratorium. 


\section{HASIL PENELITIAN}

\section{Analisa Dan Pengukuran Perangkat Keras}

Analisa dan pengukuran yang dilakukan mencakup analisa dan pengukuran pada perangkat keras yang digunakan, diantaranya :

1. Sistem Catu Daya

2. Mikrokontroler Arduino Uno

3. Sensor PIR

4. RFID atau Identifikasi Frekuensi Radio

5. CCTV

6. Modem Wavecom

7. Buzzer

8. Selenoid

\section{Analisa dan Pengukuran Sistem Catu Daya}

Pada rancangan alat yang dibuat sangat membutuhkan power supply. Power supply tersebut nantinya akan digunakan sebagai sumber catu daya untuk sumber tegangan dari Mikrokontroler. Power supply tersebut sudah merupakan modul sehingga keluarannya bisa stabil. Untuk lebih jelasnya power supply yang digunakan dapat dilihat pada gambar dibawah ini:

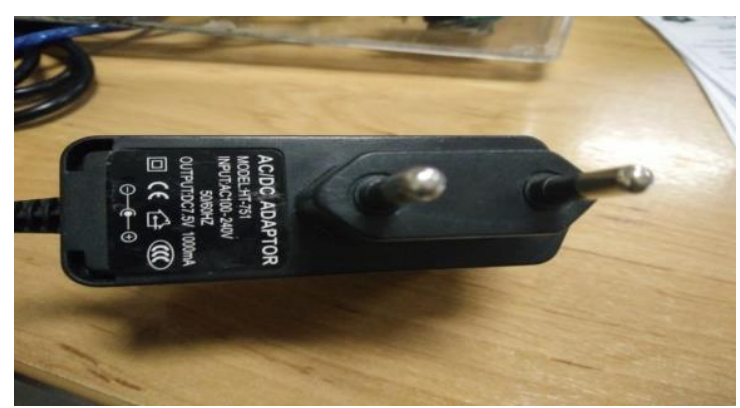

Gambar 5. Power Supply 5 VDC

Tabel 1. Hasil Pengukuran Power Supply

\begin{tabular}{|c|c|}
\hline V input power supply & V output power supply \\
\hline 220 VAC & $5 \mathrm{DC}$ \\
\hline
\end{tabular}

\section{Mikrokontroler Arduino Uno}

Pada rangkaian Mikrokontroler Arduino Uno. Arduino tersebut nantinya akan digunakan sebagai media pengolah, pengirim data maupun penerima data. Mikrokontroler akan menerima data dari sensor PIR maupun RFID, kemudian diolah dan diproses sedemikian rupa kemudian data hasil proses tadi diteruskan ke modem wavecom, CCTV, buzzer dan juga solenoid.

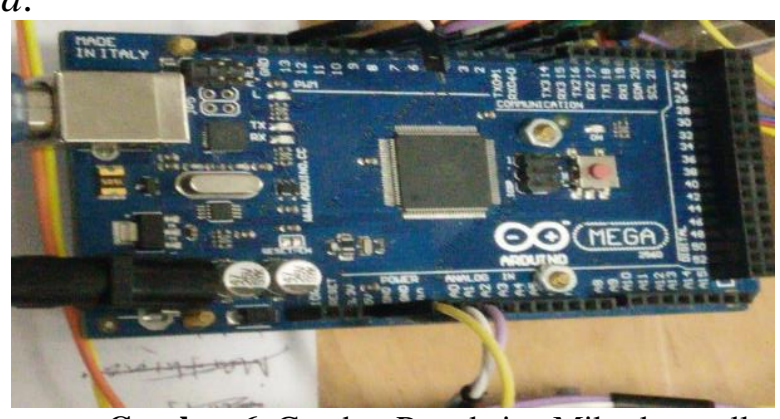

Gambar 6. Gambar Rangkaian Mikrokontroller 


\section{Sensor PIR}

Pada Sensor PIR. Sensor PIR nantinya akan digunakan sebagai media pengolah, pengirim data maupun penerima data. Mikrokontroler akan Menerima data dari sensor PIR maupun RFID, kemudian diolah dan diproses sedemikian rupa kemudian data hasil proses tadi diteruskan ke modem wavecom, CCTV, buzzer dan juga solenoid.

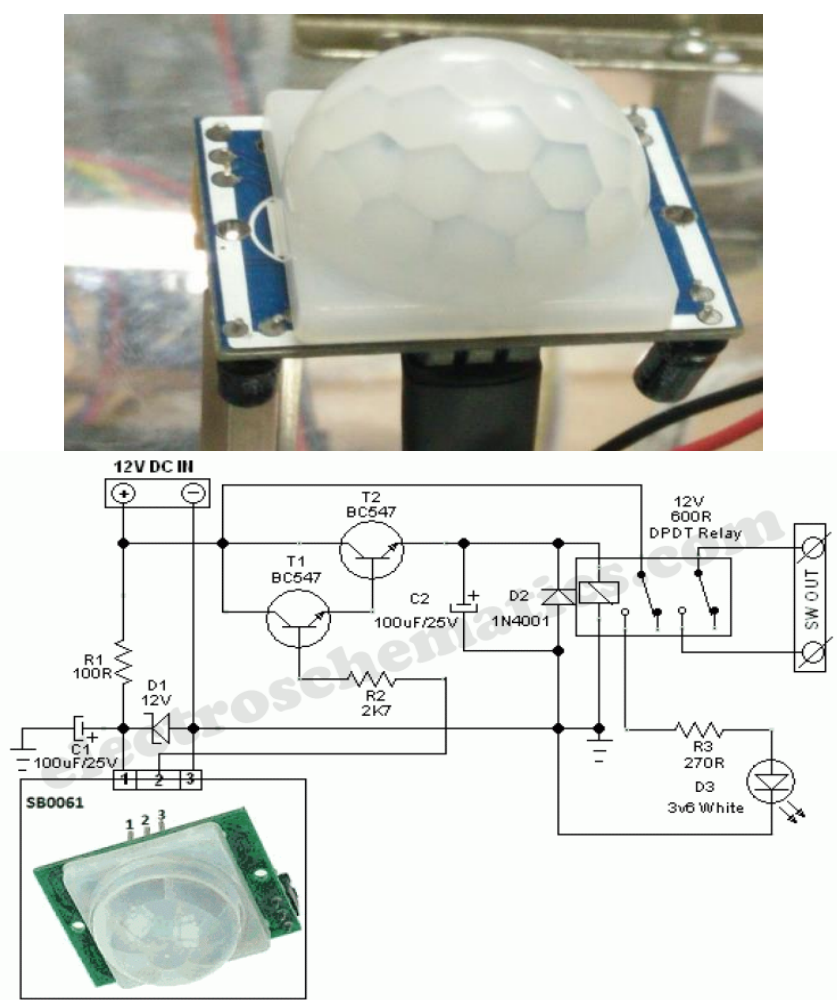

Gambar 7. Gambar Rangkaian Sensor PIR

\section{RFID (Identifikasi Frekuensi Radio)}

Pada rangkaian RFID. RFID nantinya akan digunakan sebagai sensor yang dapat membaca peralatan yang ada di laboratorium yang sebelumnya telah dipasang RFID tag.

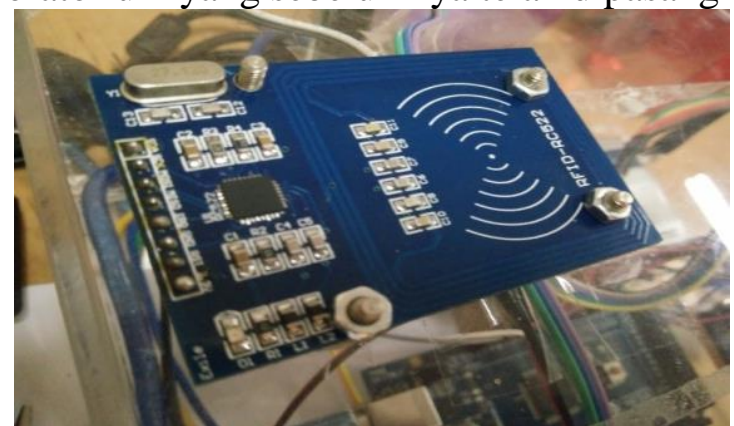

Gambar 8. Gambar Rangkaian RFID

\section{CCTV}

Pada rangkaian CCTV. CCTV tersebut nantinya akan digunakan sebagai peralatan untuk menangkap gambar pada ruangan airfield lighting system dan ditampilkan pada komputer pada ruangan server. 


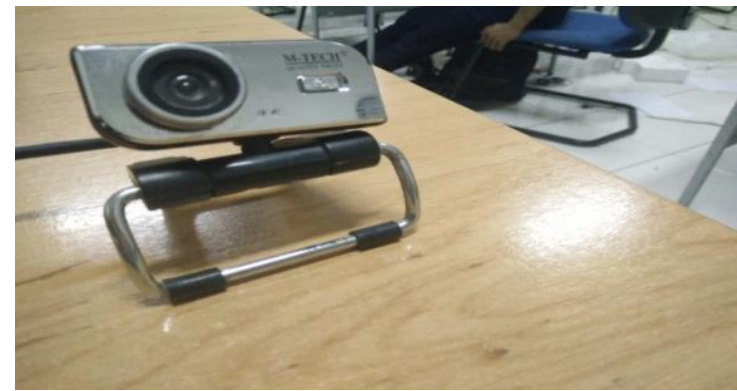

Gambar 9. Gambar CCTV

\section{Modem Wavecom}

Pada Modem Wavecom. Modem Wavecom nanti akan digunakan sebagai media untuk memberikan perintah kepada mikrokontroler guna menghidupkan atau mematikan sensor dan memberikan informasi kepada pihak keamanan bahwa terjadi indikasi pencurian didalam laboratorium Airfield lighting system.

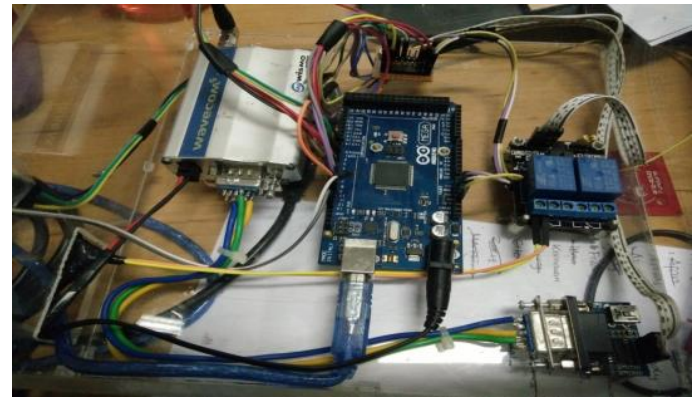

Gambar 10. Modem Wavecom

\section{Buzzer}

Buzzer disini sebagai perangkat output untuk memberikan informasi berupa suara, ketika sistem alarm diaktifkan dan ada suatu peralatan yang akan keluar melewati pintu laboratorium

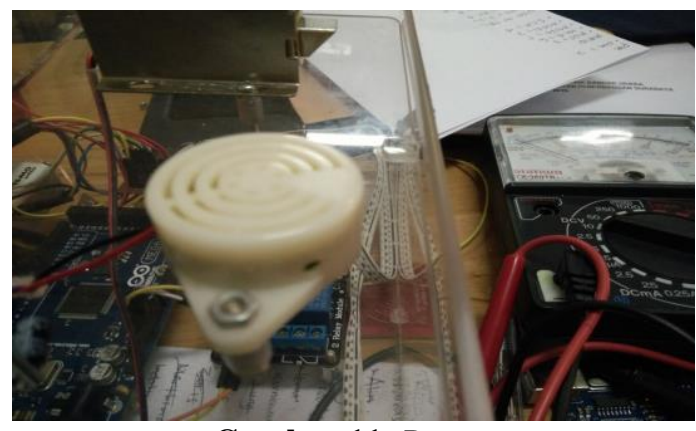

Gambar 11. Buzzer

\section{Selenoid}

Selenoid berfungsi sebagai perangkat untuk mengunci pintu terluar yang ada di laboratorium 


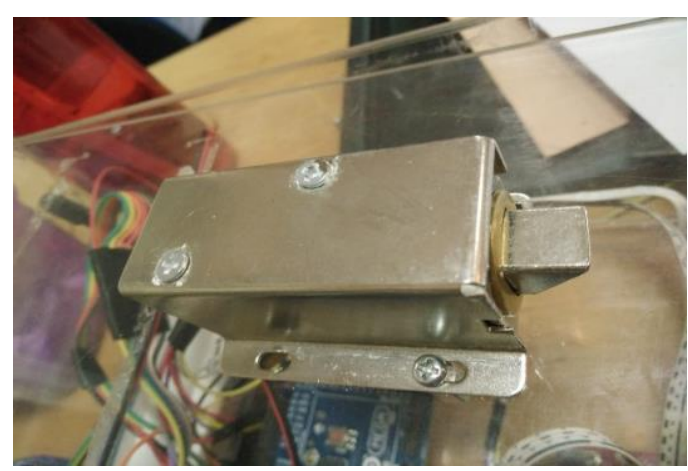

Gambar 12. Selenoid

\section{KESIMPULAN}

Dari pengamatan pada Rancangan Proteksi Otomatis Menggunakan Motion Detector, Radio Frequency Identification (RFID) Dan CCTV Berbasis SMS Gateway Di Laboratorium Airfield Lighting System Politeknik Penerbangan Surabaya”. sebagaimana yang sudah di jelaskan pada bab sebelumnya, maka selanjutnya dapat diambil kesimpulan sebagai berikut :

1. Perancangan ini difungsikan sebagai kontrol dan monitoring jarak jauh pada laboratorium airfield lighting system dengan menggunakan mikrokontroler dan sms gateway

2. Perbedaan rancangan ini dengan sebelumnya adalah sistem kontrol dapat dilakukan dengan wireless dengan menggunakan media sms untuk mengoperasikan

3. Dengan adanya sistem monitoring maka bisa mengetahui dan mengawasi kondisi dalam ruangan dan alat apa saja yang akan di pinjam oleh taruna Politeknik Penerbangan Surabaya

4. Dengan adanya sistem keamanan maka tidak perlu khawatir tentang keamanan yang ada pada laboratorium Airfield Lighting System.

\section{DAFTAR PUSTAKA}

Didik Suyoko. (2012), "Alat pengaman pintu rumah menggunakan Radio Frequency Identification (RFID) $125 \mathrm{khz}$ berbasis mikrokontroler atmega328"

Fahdly Saputra. (2008), "Sistem absensi menggunakan teknologi radio frequency identification (RFID)"

Imda Padang dan Rina Sidabutar. (2014), "Perancangan pemberitahuan informasi terjadwal berbasis sms gateway

Ipin Prasojo. (2011), "Prototype penghemat energi dan pengaman ruangan"

Simon Siregar. (2011), "Rancang bangun aplikasi sistem kontrol lampu berbasis sms gateway"

Suhenda. (2014), "Perancangan aplikasi motion detection dengan menerapkan metode clustering" 